\title{
Retraction Note to: Nicorandil accelerates recovery of neuromuscular block caused by vecuronium
}

\author{
Yuhji Saitoh, MD • Koh Kaneda, MD • Yoshitaka Fujii, MD • \\ Tsutomu Oshima, MD
}

Published online: 25 June 2015

(C) Canadian Anesthesiologists' Society 2015

\section{Retraction Note to: Can J Anesth 2001; 1: 28-33 \\ DOI 10.1007/BF03019810}

To our readers:

Further to the Expression of Concern* posted online, it is with considerable regret that the Canadian Journal of Anesthesia hereby retracts the above-cited article by Dr. Yoshitaka Fujii as a result of: 1) overwhelming evidence of fabrication relating to the fact that the distribution of many variables reported by Dr. Fujii in this study are exceedingly unlikely; ${ }^{1}$ and 2 ) the inability of Dr. Fujii's institution to attest to the integrity of the study and/ or the data conducted under its auspices, as set out in the Joint Editors-in-Chief Request for Determination of April 9, 2012. ${ }^{\dagger}$

Hilary P. Grocott, MD

Editor-in-Chief

Canadian Journal of Anesthesia

e-mail: cja_office@cas.ca
À nos lecteurs:

Faisant suite à l'Énoncé de préoccupations* publié en ligne, c'est avec un immense regret que le Journal canadien d'anesthésie réfute et retire par la présente l'article du Dr Yoshitaka Fujii cité ci-dessus pour les raisons suivantes : 1) la preuve accablante de fabrication de données constituée par le fait que la distribution des nombreuses variables décrites par le Dr Fujii dans cette étude est excessivement improbable; ${ }^{1}$ et 2) l'incapacité dans laquelle se trouve l'institution où travaillait le Dr Fujii d'attester l'intégrité de l'étude et/ou des données menées sous ses auspices, tel qu'établi dans la demande conjointe des Rédacteurs en chef aux fins de décision du 9 avril 2012..$^{\dagger}$

Hilary P. Grocott, MD

Rédacteur en chef

Journal canadien d'anesthésie

courriel: cja_office@cas.ca

\section{Reference}

1. Carlisle JB. The analysis of 168 randomised controlled trials to test data integrity. Anaesthesia 2012; 67: 521-37.
The online version of the original article can be found under doi:10.1007/BF03019810.

\footnotetext{
* http://www.springer.com/medicine/anesthesiology/journal/12630.

${ }^{\dagger}$ http://www.aaeditor.org/Fujii_Joint_EIC_Stmt.pdf (accessed April 2015).
} 